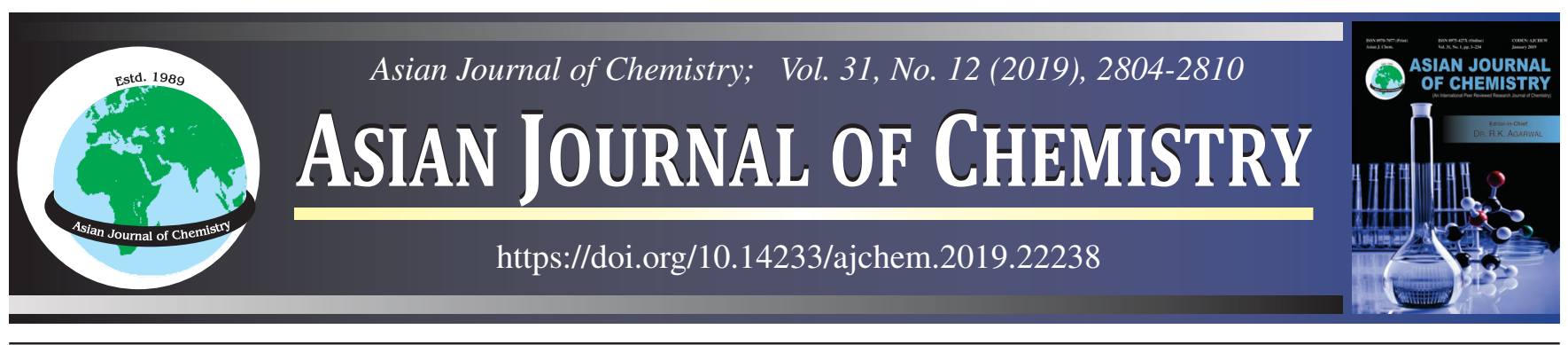

\title{
Green Synthesis of Silver Nanoparticles using Salacca zalacca Extract as Reducing Agent and It's Antibacterial Activity
}

\section{Anti Kolonial Prodjosantoso*••, Oktanio Sigit Prawoko, Maximus Pranjoto Utomo ${ }^{\circledR}$ and Lis Permana Sari ${ }^{\circledR}$}

Department of Chemistry, Yogyakarta State University, Yogyakarta, DIY 55281, Indonesia

*Corresponding author: E-mail: prodjosantoso@uny.ac.id

| Keywords: Silver nanoparticles, Salacca zalacca, Antibacterial, Escherichia coli, Staphylococcus epidermidis.

\section{INTRODUCTION}

Nanoparticles have attracted reseachers since few decades ago. The nanoparticles have better activity as result of having a wider surface area compared to the same material in a larger form [1]. The nanoparticles can be engineered in various sizes and shapes and can be used for the advancement of biotechnology $[2,3]$. Currently researchs are not only undertaken on how nanoparticles are applied, but also on how to synthesize $[4,5]$.

One of the famous nanoparticles is silver nanoparticles (AgNPs). The nanoparticles have been reported to have strong antibacterial activity. Today there are many environmental problems and diseases caused by pathogenic bacteria. The researchers developed many methods to save the environment from pathogenic bacteria, including the use of AgNPs. It has been reported that AgNPs can kill up to 650 types of pathogenic microorganisms, including bacteria, viruses, parasites and fungi [6].

The synthesis of silver nanoparticles was studied extensively using physical and chemical methods. The development of reliable technology for producing nanoparticles is an important aspect of nanotechnology [7,8]. The physical method has some drawbacks, for example, typically require high energy consumption and costs for the operation of some modern equipments [9]. The chemical method requires chemicals that are harmful to the environment [10]. On the other hand, biological method, using microorganisms and enzymes, has been suggested as the alternative methods that are environmentally friendly [11-13]. The characteristics of silver nanoparticles produced depend on the conditions of the preparation applied such as the preparation temperature. Generally, the formation of silver nanoparticles at high temperatures takes place faster than at low temperatures. The concentration of silver nitrate solution affects the number of nanoparticles produced. The greater the concentration of silver nitrate solution used, the more nanoparticles produced, but the size of nanoparticles tends to be larger compared to using a lower concentration of silver nitrate $[14,15]$.

The uses of plant extracts as reducing agents in nanoparticles synthesis are environmentally friendly, clean, non-toxic and inexpensive, The methods produce nanoparticles in various

This is an open access journal, and articles are distributed under the terms of the Attribution 4.0 International (CC BY 4.0) License. This license lets others distribute, remix, tweak, and build upon your work, even commercially, as long as they credit the author for the original creation. You must give appropriate credit, provide a link to the license, and indicate if changes were made. 
shapes, sizes and morphologies [16-18]. The use of plant extracts is beneficial rather than microorganisms, because multistep or complex procedures such as microorganism isolation, identification, growth optimization, culture preparation and maintenance are not required. Furthermore, the use of plant in nanoparticles synthesis is inexpensive, faster than using microorganisms and easily applied for large-scale productions $[19,20]$.

Indonesia is one of the countries in the world that has enormous biodiversity, the wealth of natural resources, especially plants, which is very supportive for conducting research relating with the natural products. This situation is very beneficial to do research such as the use of plants for nanoparticle synthesis. Banana peel [21-23], lemon juice [24,25], black tea [26,27] and papaya fruit extracts [28] contain chemical compounds that may act as reducing agents which have been used in the preparation of AgNPs. Secondary metabolites contained in plants, such as terpenoids [29] and flavonoids [30] are believed to play a main role in the synthesis process of silver nanoparticles.

One of the many potential plants in Indonesia is snake fruit (Salacca zalacca) plants. Salacca zalacca is a tropical fruit plant that is widely found in the Special Region of Yogyakarta, Indonesia. Salacca zalacca bears fruit throughout the season and are pest and disease resistances [31]. Salacca zalacca fruit contains phenolic compounds: alkaloids, saponins, flavonoids, tannins, polyphenols and vitamin C [32]. The role of the active compounds in Salacca zalacca fruit extract in reducing silver to produce AgNPs is reported.

\section{EXPERIMENTAL}

Salacca zalacca was collected from a local market of Yogyakarta, Indonesia. Silver nitrate (Merck, 99.5\%), Grampositive bacteria (Staphylococcus epidermidis) and Gramnegative bacteria (Escherichia coli) were used without any pretreatments. Bacterial culture was grown on Mueller-Hinton agar (Oxoid) media.

The UV-Vis spectrum of AgNPs was recorded as a wavelength function using Shimadzu UV-2400 PC Series UV-Vis Spectrophotometer (Japan). A number of samples of AgNPs colloids were inserted into cuvettes and measured using a UVvisible spectrophotometer in a wavelength range of 300-700 $\mathrm{nm}$. The XRD diffractograms of AgNPs were collected by using Rigaku Miniflex 600 Benchtop X-Ray Diffraction (XRD) which was operated at $40 \mathrm{kV}$ and $15 \mathrm{~mA}, \mathrm{Cu}-\mathrm{K} \alpha$ radiation with $\lambda=1.54 \AA$ in the $2 \theta$ range of $5-90^{\circ}$. The shape and size of AgNPs were obsered using JEOL JEM-1400 transmission electron microscopy. One drop of colloidal AgNPs was placed on a TEM grid made of carbon-coated copper and air dried. The TEM was operated at $80 \mathrm{kV}$. Functional groups found in Salacca zalacca extract, which serves as bioreductor were observed using Fourier transform infrared (FTIR) Thermo Nicolet Avatar 360 operated in the wavenumber range $4000-400 \mathrm{~cm}^{-1}$.

Preparation of Salacca zalacca extract: A cleanly washed Salacca zalacca $(100 \mathrm{~g})$ was cut into small pieces and followed by the addition of $100 \mathrm{~mL}$ of aquadest. The mixture was blended for $5 \mathrm{~min}$ and filtered off by using Whatman No. 1 filter paper on a Buchner funnel kit equipped with a vacuum pump. The filtrate obtained was then used as a reducing agent for the preparation of AgNPs.
Preparation of AgNPs using Salacca zalacca extract: A mixture of $4 \mathrm{~mL}$ of Salacca zalacca extract and $200 \mathrm{~mL}$ of $\mathrm{AgNO}_{3}$ solution was prepared. The mixture was incubated at room temperature in the dark environment. The measuring absorbance of AgNPs was conducted at $5 \mathrm{~min}, 15 \mathrm{~min}, 30 \mathrm{~min}$, $60 \mathrm{~min}, 24 \mathrm{~h}, 48 \mathrm{~h}$ and $72 \mathrm{~h}$ of incubation. The variation concentration of $\mathrm{AgNO}_{3}$ solution was determined at $0.25 \mathrm{mM}, 1.25 \mathrm{mM}$ and $2 \mathrm{mM}$. The effect of the preparation temperature was determined by reacting the mixtures at 30,50 and $75^{\circ} \mathrm{C}$ for $5 \mathrm{~min}$.

Antibacterial activity of silver nanoparticles: The antibacterial activity of AgNPs was studied by measuring the growth inhibition zone diameter against Escherichia coli and Staphylococcus epidermidis bacteria using Kirby-Bauer method. A total of $100 \mu \mathrm{L}$ of bacterial suspension was poured into $15 \mathrm{~mL}$ media so that sterilized Mueller-Hinton was then observed and measured in the inhibition zone diameter every $3 \mathrm{~h}$ for $48 \mathrm{~h}$. Salacca zalacca extract and $1.25 \mathrm{mM} \mathrm{AgNO}_{3}$ solution were used as a control. The standard antibiotic chloramphenicol was used as a comparison. The data obtained was analyzed statistically using the SPSS program (Version 22, IBM Corporation) with one way ANOVA test, LSD (least significant differences) and t-indepedent test methods.

\section{RESULTS AND DISCUSSION}

The AgNPs was produced through a reduction reaction process of silver nitrate solution using Salacca zalacca extract as reducing agent. The mixture indicated colour was changed from colourless to reddish brown and dark brown. Visually the occuring colour changes indicated the growth of AgNPs, as $\mathrm{Ag}^{+}$ions was reduced to $\mathrm{Ag}^{0}$ by the active molecules of Salacca zalacca extract.

Nanoparticles were observe using UV-visible spectrophotometer to study the surface plasmon resonance (SPR) of silver nanoparticles. The absorptions of AgNPs after $5 \mathrm{~min}$, $15 \mathrm{~min}, 30 \mathrm{~min}, 60 \mathrm{~min}, 24 \mathrm{~h}, 48 \mathrm{~h}$ and $72 \mathrm{~h}$ of incubations were measured in the range $300-700 \mathrm{~nm}$ in order to describe the absorption peak as seen in Fig. 1. The surface plasmon resonance was difined in the range of $410-460 \mathrm{~nm}$, which is consistent with the finding of Jensen et al. [33] and Yeshchenko [34]. The highest absorption is observed in sample incubated for $48 \mathrm{~h}$ (Fig. 1). This describes the optimum amount of AgNPs formed in the mixture.

The effect of $\mathrm{AgNO}_{3}$ precursor concentration to AgNPs was observed by using a UV-visible spectrophotometer. The $1.25 \mathrm{mM}$ and $2 \mathrm{mM} \mathrm{AgNO}_{3}$ solution caused a colour change from colourless to reddish brown after 2 days incubation. However, $0.25 \mathrm{mM} \mathrm{AgNO}_{3}$ solution caused the colour unchange and indicated no absorption as result of absent or slowly growth of AgNPs occured (Fig. 2). The optimum absorbance (0.417) is observed at a wavelength of $434 \mathrm{~nm}$ for solution prepared using $1.25 \mathrm{mM} \mathrm{AgNO}_{3}$.

The temperature of synthesis of AgNPs affects the colour of mixture and the peak of absorption of silver nanoparticles. At $30{ }^{\circ} \mathrm{C}$, the mixture colour changes slowly, but when the mixture was heated at $50^{\circ} \mathrm{C}$ and $75^{\circ} \mathrm{C}$ the reduction process runs faster and the colour changes to reddish brown faster. The highest absorption was observed from the mixture heated at $75^{\circ} \mathrm{C}$ as shown in Fig. 3. 


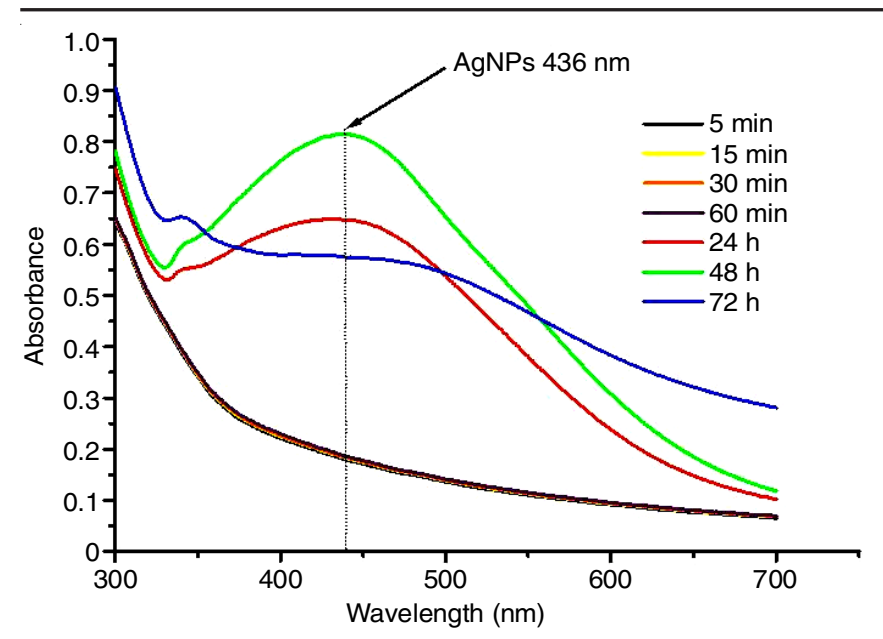

Fig. 1. Spectra of UV-visible absorption of AgNPs solution after various time of incubation

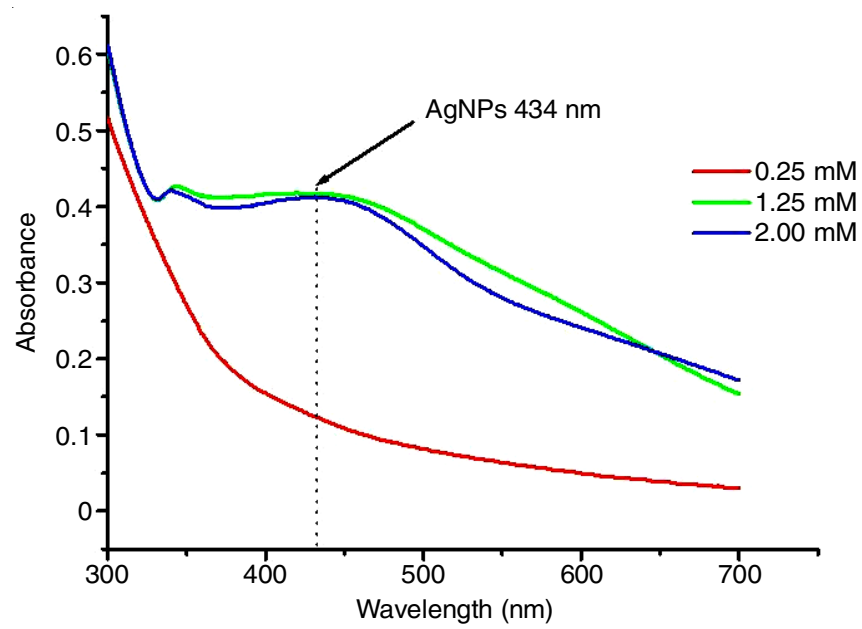

Fig. 2. Spectra of UV-visible absorption of AgNPs solution prepared using various concentration of $\mathrm{AgNO}_{3}$

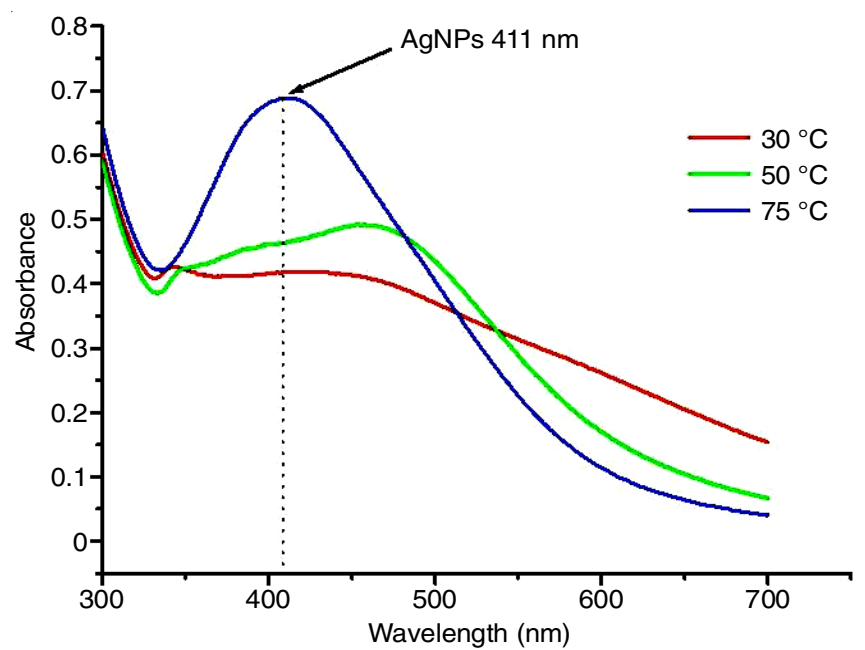

Fig. 3. Spectra of UV-visible absorption of AgNPs solution prepared at various heating temperature

The surface plasmon resonance (SPR) is shifted to the longer wavelength with the increasing particle size. The increase of the reaction temperature causes the absorption spectrum appeared as a narrow peak at a shorter wavelength $(411 \mathrm{~nm}$ at 75 ${ }^{\circ} \mathrm{C}$ ) indicated the formation of smaller nanoparticles of silver, while at lower temperature a peak is observed at longer wavelengths $\left(434 \mathrm{~nm}\right.$ at $30^{\circ} \mathrm{C}$ ) indicated the the larger size of silver nanoparticles. The results of this study are consistent with the previous studies reported by Ibrahim et al. [21] stated that at $100^{\circ} \mathrm{C}, \mathrm{UV}-\mathrm{Vis}$ spectrum showed a narrow peak at a short wavelength of $412 \mathrm{~nm}$, which indicated the formation of smaller nanoparticles of silver. Whereas at $30^{\circ} \mathrm{C}$, the peak is observed at a longer wavelength of $440 \mathrm{~nm}$, which indicated the formation of the larger size of AgNPs. These fact indicate that when the temperature increases, the reactants will form smaller nanoparticles faster.

The samples were characterized using the XRD method to confirm the presence, to determine the structural information and to determine the particle size of AgNPs. The XRD pattern of AgNPs is seen in Fig. 4. The XRD diffractogram of AgNPs indicates four different diffraction peaks at $2 \theta=38.11^{\circ}, 44.30^{\circ}$, $64.38^{\circ}$ and $77.35^{\circ}$, which can be indexed to (111), (200), (220) and (311), respectively. This XRD difractogram is comparable with JCPDS (file No. 04-0783) for silver having a face centered cubic structure with a space group of $F \mathrm{~m} 3 \mathrm{~m}$. These findingss are also consistent with the report of Ibrahim et al. [21]. In

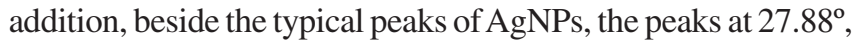
$32.19^{\circ}$ and $46.19^{\circ}$ are also observed. It is possible that the peaks indicate the presence of organic crystalline phases in Salacca zalacca extract.

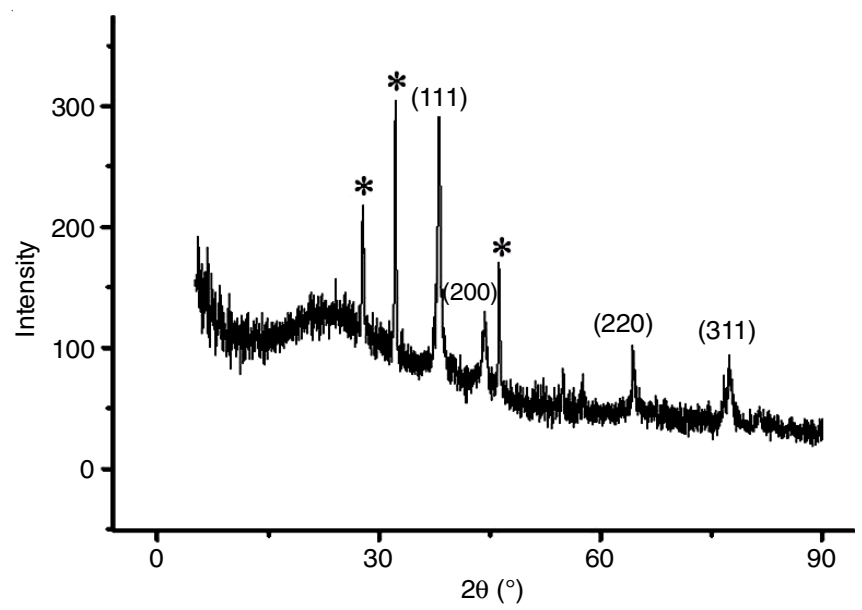

Fig. 4. Diffractogram of AgNPs ( $*=$ unknown crystalline organic phases)

The AgNPs particle size is calculated using a modified Debye-Scherrer equation with the $\beta$ is the full width at half maximum (FWHM), $\mathrm{K}$ is 0.9 and the $\lambda$ is the wavelength of $\mathrm{X}$-rays $(1.54059 \AA)$. The Debye-Scherrer equation shows that the value of particle size produced will be inversely proportional to the value of FWHM. The calculated $\ln 1 / \cos \theta$ and $\ln \beta$ are listed in Table-1.

The relationship between $\ln 1 / \cos \theta$ (x-axis) and $\ln \beta$ (yaxis) generates the intercept valued $\ln K \lambda / D$. Thus, the particle size $\mathrm{D}$ can be expressed as $\mathrm{D}=(\mathrm{K} \lambda / \mathrm{e}$ (intercept value), where the intercept is -4.8047 . Thus, the particle size $\mathrm{D}$ is determined as $16.93 \mathrm{~nm}$.

The TEM of selected AgNPs sample is displayed in Fig. 5. The AgNPs is spherical in shape and the size of AgNPs was estimated using the ImageJ software (Version 1.52a, Wayne Rasband, National Institute of Health, USA) and the corres- 
TABLE-1

CALCULATION OF $(\ln 1 / \cos \theta)$ AND $(\ln \beta)$

\begin{tabular}{|c|c|c|c|c|c|}
\hline $2 \theta\left({ }^{\circ}\right)$ & Lattice planes & $1 / \cos \theta$ & FWHM $(\beta) \mathrm{rad}$ & $\ln 1 / \cos \theta(x)$ & $\ln \beta(y)$ \\
\hline 38.11 & $\left(\begin{array}{lll}1 & 1 & 1\end{array}\right)$ & 1.057977238 & 0.008198889 & 0.056358819 & -4.803756635 \\
\hline 44.30 & $\left(\begin{array}{lll}2 & 0 & 0\end{array}\right)$ & 1.079680461 & 0.011513333 & 0.076665128 & -4.464249495 \\
\hline 64.38 & $\left(\begin{array}{lll}2 & 2 & 0\end{array}\right)$ & 1.181678853 & 0.004710000 & 0.166936184 & -5.358067371 \\
\hline 77.35 & $\left(\begin{array}{lll}3 & 1 & 1\end{array}\right)$ & 1.280896592 & 0.012385556 & 0.247560295 & -4.391224324 \\
\hline
\end{tabular}

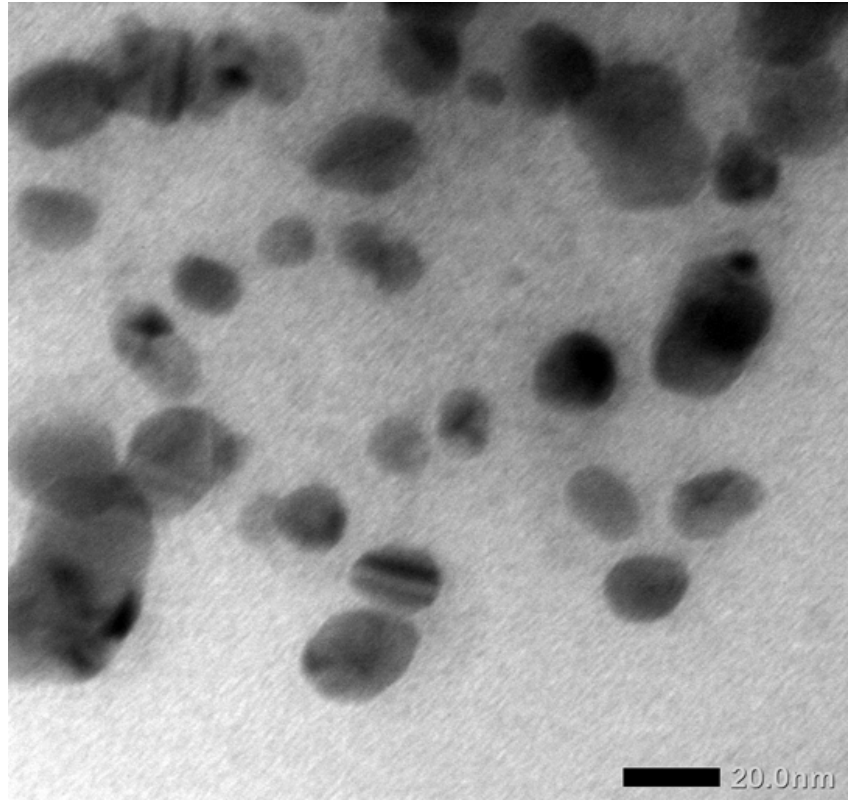

Fig. 5. TEM micrograph of AgNPs

ponding histogram of particle size distribution was determined using Origin software (Version 6.1, OriginLab Corporation Northampton, MA) (Fig. 6). The AgNPs size is difined as 14.2 $\pm 2.6 \mathrm{~nm}$. This size is reasonable the same with the size calculated using the Debye-Scherrer equation and compared with the reported plant extracts as reducing agents (Table-2).

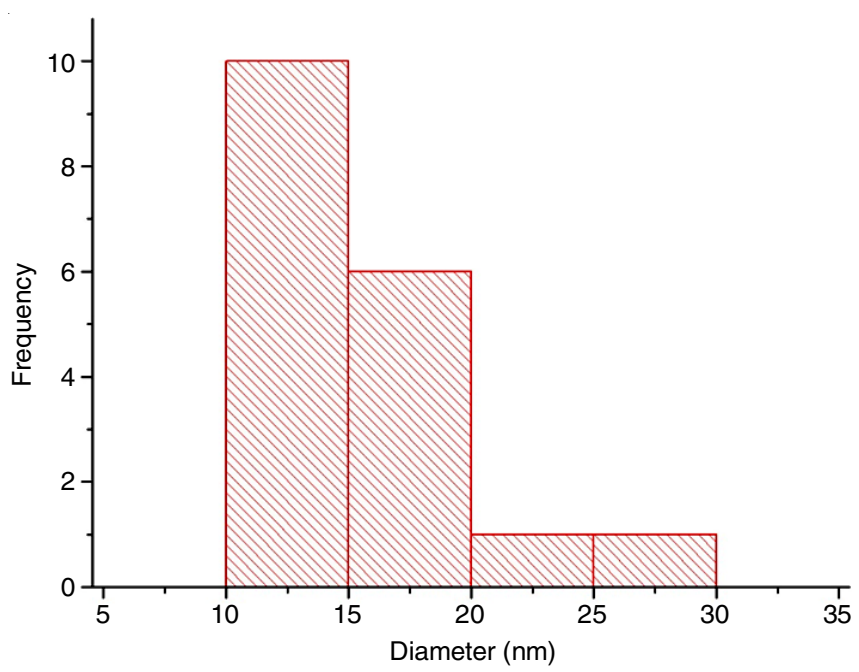

Fig. 6. Distribution of AgNPs size

FTIR analysis: The FTIR spectra of AgNPs and Salacca zalacca extract can be seen in Fig. 7. The FTIR spectra are somewhat the same with Patil et al. [40], who stated the presence of $\mathrm{O}-\mathrm{H}$ bond stretching at $3286 \mathrm{~cm}^{-1}$, nitrile group at $2222 \mathrm{~cm}^{-1}$, $\mathrm{C}=\mathrm{O}$ bond at $1689 \mathrm{~cm}^{-1}$ and $\mathrm{C}-\mathrm{X}$ bond stetching at $736 \mathrm{~cm}^{-1}$.
TABLE-2

SHAPE AND SIZE OF AgNPS PREPARED

USING VARIOUS PLANT EXTRACTS

\begin{tabular}{lll}
\hline \multicolumn{1}{c}{ Plant extracts } & \multicolumn{1}{c}{$\begin{array}{c}\text { Shape and size of } \\
\text { AgNPs (nm) }\end{array}$} & Ref. \\
\hline Musa paradisiaca & Spherical, 23.7 $\mathrm{nm}$ & {$[35]$} \\
Citrus limon & Spherical, 25-50 nm & {$[36]$} \\
Butea monosperma leaf & Spherical, 20-50 nm & {$[37]$} \\
Rosa chinensis flower & Spherical, 5-10 nm & {$[38]$} \\
Caltropis procera fruit & Spherical, 20-40 nm & {$[39]$} \\
\hline
\end{tabular}

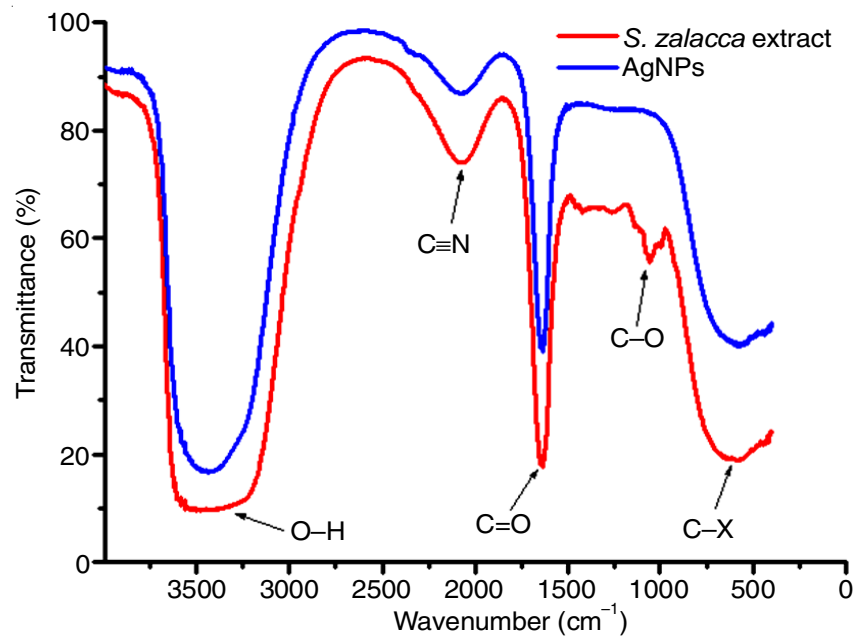

Fig. 7. FTIR spectra of AgNPs and the Salacca zalacca extract

Parthiban et al. [41] suggested the presence of C-O at 1053 $\mathrm{cm}^{-1}, \mathrm{C}=\mathrm{O}$ at $1622 \mathrm{~cm}^{-1}, \mathrm{O}-\mathrm{H}$ stretching at $3430 \mathrm{~cm}^{-1}$ and $\mathrm{C}-\mathrm{X}$ stetching at $618 \mathrm{~cm}^{-1}$. Table-3 listed hydroxyl, carbonyl and nitrile functional groups in flavonoids, tannins, alkaloids, phenolics and vitamin C found in Salacca zalacca extract acted as bioreductors in the formation of silver nanoparticle.

TABLE-3

ASSIGNMENT OF AgNPs AND Salacca zalacca EXTRACT

\begin{tabular}{|c|c|c|}
\hline \multicolumn{2}{|c|}{ Wavenumber $\left(\mathrm{cm}^{-1}\right)$} & \multirow{2}{*}{ Assignments } \\
\hline Salacca zalacca extract & AgNPs & \\
\hline 3479 & 3439 & O-H stretching \\
\hline 2070 & 2077 & $\mathrm{C} \equiv \mathrm{N}$ stretching \\
\hline 1634 & 1633 & $\mathrm{C}=\mathrm{O}$ stretching \\
\hline 1055 & - & $\mathrm{C}-\mathrm{O}$ stretching \\
\hline 582 & 584 & $\mathrm{C}-\mathrm{X}$ stretching \\
\hline
\end{tabular}

Antibacterial activity: The antibacterial activity of AgNPs was studied by measuring growth inhibition zone by agar diffusion method (Kirby-Baurer). Escherichia coli and Staphylococcus epidermidis bacteria were inoculated on Mueller Hinton Agar media and incubated for 2 days. The inhibition of growth was measured every 3 h. Figs. 8 and 9 illustrate that the growth inhibition increasing as the length of incubation period, but after $24 \mathrm{~h}$ of incubation, the growth inhibition is tend to be 


\begin{tabular}{|c|c|c|c|c|c|c|c|c|c|c|}
\hline \multicolumn{11}{|c|}{$\begin{array}{c}\text { TABLE-4 } \\
\text { ONE WAY ANOVA TEST OF THE INFLUENCE OF THE SAMPLE ON THE INHIBITION } \\
\text { ZONE DIAMETER OF Staphylococcus epidermidis AND Escherichia coli BACTERIA }\end{array}$} \\
\hline & \multicolumn{5}{|c|}{ Staphylococcus epidermidis } & \multicolumn{5}{|c|}{ Escherichia coli } \\
\hline & $\begin{array}{l}\text { Sum of } \\
\text { squares }\end{array}$ & df & $\begin{array}{c}\text { Mean } \\
\text { square }\end{array}$ & $\mathrm{F}$ & Sig. & $\begin{array}{l}\text { Sum of } \\
\text { squares }\end{array}$ & df & $\begin{array}{c}\text { Mean } \\
\text { square }\end{array}$ & $\mathrm{F}$ & Sig. \\
\hline Between groups & 2023.319 & 3 & 674.440 & 151.610 & .000 & 4378.238 & 3 & 1459.413 & 252.324 & .000 \\
\hline Within groups & 836.321 & 188 & 4.449 & & & 1087.371 & 188 & 5.784 & & \\
\hline Total & 2859.640 & 191 & & & & 5465.609 & 191 & & & \\
\hline
\end{tabular}

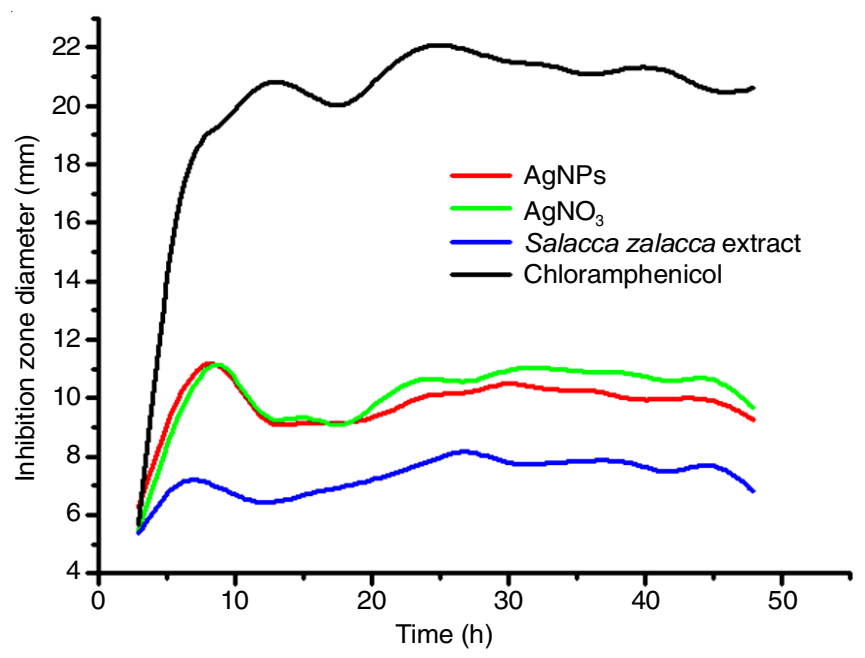

Fig. 8. Inhibition zone of Escherichia coli bacteria

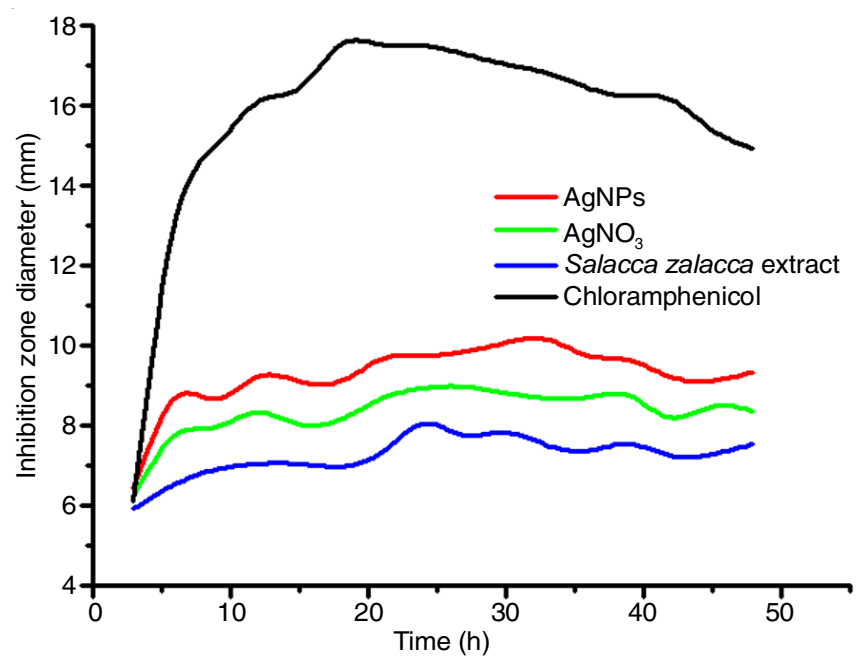

Fig. 9. Inhibition zone of Staphylococcus epidermidis bacteria

constant. At this stage, it is possible the bacteria have reached the optimum point of growth.

The mechanism of AgNPs against microorganisms is initiated by the attachments of AgNPs to the negative charge of cell surface, changing the physical and chemical properties of cell membranes and cell walls, and interfering of important functions such as permeability, osmoregulation, electron transport and respiration. The AgNPs can cause massive damage to the bacterial cells by permeating cells, followed by interacting with DNA, proteins, other phosphorus and sulfur-containing cell constituents [42].

The diameter of growth inhibition zone was calculated statistically using the SPSS program (Version 22, IBM Corporation). Statistical tests were carried out including one way
ANOVA test, least significant differences (LSD) and t-independent test. One way ANOVA test was conducted to assess the significant differences of samples (AgNPs, $\mathrm{AgNO}_{3}$, Salacca zalacca extract and chloramphenicol) affecting the diameter of the growth inhibition zone. The results of one way ANOVA test are presented in Table-4. Based on the one way ANOVA test, the samples influence the inhibition zone diameter of Staphylococcus epidermidis and Escherichia coli bacteria $(\mathrm{P}<0.05)$.

The ANOVA is followed by LSD test to assess the difference between samples in terms of the inhibition zone diameter. The LSD test summary is presented in Table-5. LSD test between samples of AgNPs with $\mathrm{AgNO}_{3}$ do not indicate a significant difference to the inhibition zone diameter of Escherichia coli growth at the $95 \%$ confidence level. The significant difference to the inhibition zone diameter is observed for the rest of the samples.

TABLE-5

LSD TEST SUMMARY OF Staphylococcus epidermidis AND Escherichia coli INHIBITION ZONE DIAMETERS

\begin{tabular}{lcc}
\hline \multirow{2}{*}{\multicolumn{1}{c}{ Between sample test }} & \multicolumn{2}{c}{$\begin{array}{c}\text { Diameter of growth inhibition } \\
\text { zone against bacteria }\end{array}$} \\
\cline { 2 - 3 } & $\begin{array}{c}\text { S. } \\
\text { epidermidis }\end{array}$ & E. coli \\
\hline $\mathrm{AgNPs}$ vs. AgNO & Significant & Not significant \\
$\mathrm{AgNPs}$ vs. Salacca zalacca extract & Significant & Significant \\
$\mathrm{AgNPs}$ vs. Chloramphenicol & Significant & Significant \\
$\mathrm{AgNO}_{3}$ vs. Salacca zalacca extract & Significant & Significant \\
$\mathrm{AgNO}_{3}$ vs. Chloramphenicol & Significant & Significant \\
Extract $v$ vs. Chloramphenicol & Significant & Significant \\
\hline
\end{tabular}

The t-independent test is conducted to asses significant differences between the test samples against Escherichia coli and Staphylococcus epidermidis bacteria. The t-independent test results are summarized in Table-6. The AgNPs and Salacca zalacca extract do not show difference significantly to the inhibition zone growth of Escherichia coli and Staphylococcus epidermidis bacteria, however $\mathrm{AgNO}_{3}$ and chloramphenicol indicate significant differences (Table-7).

TABLE-6

COMPARISON OF INHIBITON GROWTH ZONE DIAMETER

OF Escherichia coli AND Staphylococcus epidermidis BACTERIA WITH SAME CONCENTRATIONS OF Salacca zalacca EXTRACT BY INDEPENDENT t-TEST ANALYSIS

\begin{tabular}{cc}
\hline Sample test & $\begin{array}{c}\text { Diameter of growth inhibition zone } \\
\text { between } \text { E. coli } \text { and } S \text {. epidermidis bacteria }\end{array}$ \\
\hline $\mathrm{AgNPs}^{\mathrm{AgNO}}{ }_{3}$ & Not different \\
Salacca zalacca extract & Different \\
Chloramphenicol & Not different \\
\end{tabular}


The Gram-negative bacteria (E. coli) inhibites a larger zone diameter than the Gram-positive bacteria (S. epidermidis) (Table-7). This may be caused by the difference cell wall compositions. The cell walls of Gram-positive bacteria are composed of peptidoglycan thick layers consisting of $\mathrm{N}$-acetylglucosamine (NAG), $N$-acetylmuramic (NAM) acids and tetrapeptides connected by short peptide bonds. This rigid structure causes the bacterial cell wall difficult to be penetrated by AgNPs. In contrast, the cell wall of Gram-negative bacteria is composed of thin peptidoglycan layers [43]. The antibacterial activity of AgNPs prepared by using Salacca zalacca extract indicates a medium antibacterial activity.

\begin{tabular}{ccc}
\multicolumn{3}{c}{ TABLE-7 } \\
GROWTH INHIBITION ZONE DIAMETER Escherichia coli \\
AND Staphylococcus epidermidis BACTERIA \\
\hline \multirow{2}{*}{ Sample } & Diameter of inhibition zone (mm) \\
\cline { 2 - 3 } & E. coli & S. epidermidis \\
\hline $\mathrm{AgNPs}_{\mathrm{AgNO}_{3}}$ & 9.6 & 9.2 \\
Salacca zalacca extract & 9.9 & 8.3 \\
Chloramphenicol & 7.2 & 7.2 \\
\hline
\end{tabular}

\section{Conclusion}

Salacca zalacca extract was successfully used as a reducing agent in the preparation of AgNPs. The AgNPs is spherical in shape with a face centered cubic (FCC) structure. The diameter size of AgNPs is found to be $14.2 \pm 2.6 \mathrm{~nm}$ with surface plasmon resonance (SPR) in the range of $410-460 \mathrm{~nm}$. The main functional groups, namely carbonyl, hydroxyl and nitrile groups, in Salacca zalacca extract have a responsible as bioreductors in the synthesis of AgNPs. The AgNPs indicate antibacterial activities against Gram-negative bacteria (Escherichia coli) and Gram-positive bacteria (Staphylococcus epidermidis).

\section{CONFLICT OF INTEREST}

The authors declare that there is no conflict of interests regarding the publication of this article.

\section{REFERENCES}

1. J.B. Sambur and P. Chen, Annu. Rev. Phys. Chem., 65, 395 (2014); https://doi.org/10.1146/annurev-physchem-040513-103729.

2. $\quad$ N.P. Truong, M.R. Whittaker, C.W. Mak and T.P. Davis, Expert Opin. Drug Deliv., 12, 129 (2015);

https://doi.org/10.1517/17425247.2014.950564.

3. A. Banerjee, J. Qi, R. Gogoi, J. Wong and S. Mitragotri, J. Control. Rel., 238, 176 (2016);

https://doi.org/10.1016/j.jconrel.2016.07.051.

4. M. Kim, S. Osone, T. Kim, H. Higashi and T. Seto, KONA Powder Particle J., 34, 80 (2017); https://doi.org/10.14356/kona.2017009.

5. S. Panigrahi, S. Kundu, S. Ghosh, S. Nath and T. Pal, J. Nanopart. Res., 6, 411 (2004); https://doi.org/10.1007/s11051-004-6575-2.

6. L. Mpenyana-Monyatsi, N.H. Mthombeni, M.S. Onyango and M.N.B. Momba, Int. J. Environ. Res. Public Health, 9, 244 (2012); https://doi.org/10.3390/ijerph9010244.

7. P. Spicer, Chem. Eng. Res. Des., 83, 1283 (2005); https://doi.org/10.1205/cherd.05087.

8. K. Wegner, P. Piseri, H.V. Tafreshi and P. Milani, J. Phys. D Appl. Phys., 39, R439 (2006); https://doi.org/10.1088/0022-3727/39/22/R02.
9. A.U. Khan, N. Malik, M. Khan, M.H. Cho and M.M. Khan, Bioprocess Biosyst. Eng., 41, 1 (2018); https://doi.org/10.1007/s00449-017-1846-3.

10. V.V. Makarov, A.J. Love, O.V. Sinitsyna, S.S. Makarova, I.V. Yaminsky, M.E. Taliansky and N.O. Kalinina, Acta Nature, 6, 35 (2014); https://doi.org/10.32607/20758251-2014-6-1-35-44.

11. P. Mukherjee, A. Ahmad, D. Mandal, S. Senapati, S.R. Sainkar, M.I. Khan, R. Parishcha, P.V. Ajaykumar, M. Alam, R. Kumar and M. Sastry, Nano Lett., 1, 515 (2001);

https://doi.org/10.1021/n10155274.

12. N. Kulkarni and U. Muddapur, J. Nanotechnol., 2014, 1 (2014); https://doi.org/10.1155/2014/510246.

13. S. Pandey, G.K. Goswami and K.K. Nanda, Int. J. Biol. Macromol., 51, 583 (2012); https://doi.org/10.1016/j.ijbiomac.2012.06.033.

14. M.H. Ullah, K. Il and C.-S. Ha, Mater. Lett., 60, 1496 (2006); https://doi.org/10.1016/j.matlet.2005.11.058.

15. T. Silva, L.R. Pokhrel, B. Dubey, T.M. Tolaymat, K.J. Maier and X. Liu, Sci. Total Environ., 468-469, 968 (2014); https://doi.org/10.1016/j.scitotenv.2013.09.006.

16. B.D. Chithrani, A.A. Ghazani and W.C.W. Chan, Nano Lett., 6, 662 (2006); https://doi.org/10.1021/n1052396o.

17. A. Albanese, P.S. Tang and W.C.W. Chan, Annu. Rev. Biomed. Eng., 14, 1 (2012); https://doi.org/10.1146/annurev-bioeng-071811-150124.

18. C. Kinnear, T.L. Moore, L. Rodriguez-Lorenzo, B. Rothen-Rutishauser and A. Petri-Fink, Chem. Rev., 117, 11476 (2017); https://doi.org/10.1021/acs.chemrev.7b00194.

19. N.K. Ojha, G.V. Zyryanov, A. Majee, V.N. Charushin, O.N. Chupakhin and S. Santra, Coord. Chem. Rev., 353, 1 (2017); https://doi.org/10.1016/j.ccr.2017.10.004.

20. S. Panja, I. Chaudhuri, K. Khanra and N. Bhattacharyya, Asian Pac. J. Trop. Dis., 6, 549 (2016); https://doi.org/10.1016/S2222-1808(16)61085-X.

21. R.A. Abdol Aziz, S.F. Abd Karim, U.K. Ibrahim and N. Sanuddin, Key Eng. Mater, 797, 262 (2019); https://doi.org/10.4028/www.scientific.net/KEM.797.262.

22. P. Thongnopkun, M. Jamkratoke and Y. Jitkam, J. Phys. Conf. Ser., 1144, 012159 (2018); https://doi.org/10.1088/1742-6596/1144/1/012159.

23. T. Kokila, P.S. Ramesh and D. Geetha, Appl. Nanosci., 5, 911 (2015); https://doi.org/10.1007/s13204-015-0401-2.

24. E.M. Schneider, A. Bärtsch, W.J. Stark and R.N. Grass, J. Chem. Educ., 96, 540 (2019); https://doi.org/10.1021/acs.jchemed.8b00114.

25. S. Hussain, S.A. Al-Thabaiti and Z. Khan, Bioprocess Biosyst. Eng., 37, 1727 (2014); https://doi.org/10.1007/s00449-014-1145-1.

26. M.J. Uddin, B. Chaudhuri, K. Pramanik, T.R. Middya and B. Chaudhuri, Mater. Sci. Eng. B, 177, 1741 (2012); https://doi.org/10.1016/j.mseb.2012.09.001.

27. R. Gröning, J. Breitkreutz, V. Baroth and R. Stephanie Müller, Eur. J. Pharm. Sci., 15, 149 (2002); https://doi.org/10.1016/S0928-0987(01)00194-4.

28. M. Farhana and V. Meera, Proceed. Technol., 24, 188 (2016); https://doi.org/10.1016/j.protcy.2016.05.026.

29. K.N. Yusof, S.S. Alias, Z. Harun, H. Basri and F.H. Azhar, Chem. Select, 3, 8881 (2018); https://doi.org/10.1002/slct.201801846.

30. A. Stephen and S. Seethalakshmi, J. Nanosci., 2013, 1 (2013); https://doi.org/10.1155/2013/126564.

31. D. Morris, Nature, 34, 316 (1886); https://doi.org/10.1038/034316a0.

32. I.R. Suica-Bunghez, S. Teodorescu, I.D. Dulama, O.C. Voinea, S. Imionescu and R.M. Ion, IOP Conf. Ser. Mater. Sci. Eng., 133, 012051 (2016); https://doi.org/10.1088/1757-899X/133/1/012051.

33. T.R. Jensen, M.D. Malinsky, C.L. Haynes and R.P. Van Duyne, J. Phys. Chem. B, 104, 10549 (2000); https://doi.org/10.1021/jp002435e.

34. E. Hutter, J.H. Fendler and D. Roy, J. Phys. Chem. B, 105, 11159 (2001); https://doi.org/10.1021/jp011424y. 
35. S. Deena, A. Dakshinamurthy and P.M. Selvakumar, Adv. Mater. Res., 1086, 7 (2015);

https://doi.org/10.4028/www.scientific.net/amr.1086.7.

36. B. Mohapatra, R. Kaintura, J. Singh, S. Kuriakose and S. Mohapatra, Adv. Mater. Lett., 6, 228 (2015);

https://doi.org/10.5185/amlett.2015.5731.

37. S. Patra, S. Mukherjee, A.K. Barui, A. Ganguly, B. Sreedhar and C.R. Patra, Mater. Sci. Eng. C, 53, 298 (2015); https://doi.org/10.1016/j.msec.2015.04.048.

38. Y. Meng and Y. Sun, J. Nanosci. Nanotechnol., 16, 3969 (2016); https://doi.org/10.1166/jnn.2016.11899.

39. W. Salem, D.R. Leitner, F.G. Zingl, G. Schratter, R. Prassl, W. Goessler, J. Reidl and S. Schild, Int. J. Med. Microbiol., 305, 85 (2015); https://doi.org/10.1016/j.ijmm.2014.11.005.
40. S. Patil, R. Venckatesh and R. Seenivasan, Int. J. Pharm. Pharm. Sci., 7, 169 (2015)

41. E. Parthiban, N. Manivannan, R. Ramanibai and N. Mathivanan, Biotechnol. Rep., 21, e00297 (2019); https://doi.org/10.1016/j.btre.2018.e00297.

42. S. Prabhu and E.K. Poulose, Int. Nano Lett., 2, 32 (2012); https://doi.org/10.1186/2228-5326-2-32.

43. S.E. Girardin, Science, 300, 1584 (2003); https://doi.org/10.1126/science.1084677. 